\title{
Review Article \\ Emerging Anticancer Potentials of Goniothalamin and Its Molecular Mechanisms
}

\author{
Mohamed Ali Seyed, ${ }^{1,2}$ Ibrahim Jantan, ${ }^{1}$ and Syed Nasir Abbas Bukhari' \\ ${ }^{1}$ Faculty of Pharmacy, Universiti Kebangsaan Malaysia (UKM), Jalan Raja Muda Abdul Aziz, 50300 Kualalumpur, Malaysia \\ ${ }^{2}$ School of Life Sciences, B.S. Abdur Rahman University, Seethakathi Estate, Vandalur, Chennai 600048, India
}

Correspondence should be addressed to Mohamed Ali Seyed; sdmdali.ali@gmail.com

Received 13 June 2014; Revised 23 July 2014; Accepted 25 July 2014; Published 28 August 2014

Academic Editor: Gautam Sethi

Copyright (C) 2014 Mohamed Ali Seyed et al. This is an open access article distributed under the Creative Commons Attribution License, which permits unrestricted use, distribution, and reproduction in any medium, provided the original work is properly cited.

\begin{abstract}
The treatment of most cancers is still inadequate, despite tremendous steady progress in drug discovery and effective prevention. Nature is an attractive source of new therapeutics. Several medicinal plants and their biomarkers have been widely used for the treatment of cancer with less known scientific basis of their functioning. Although a wide array of plant derived active metabolites play a role in the prevention and treatment of cancer, more extensive scientific evaluation of their mechanisms is still required. Styryl-lactones are a group of secondary metabolites ubiquitous in the genus Goniothalamus that have demonstrated to possess antiproliferative activity against cancer cells. A large body of evidence suggests that this activity is associated with the induction of apoptosis in target cells. In an effort to promote further research on the genus Goniothalamus, this review offers a broad analysis of the current knowledge on Goniothalamin (GTN) or 5, 6, dihydro-6-styryl-2-pyronone $\left(\mathrm{C}_{13} \mathrm{H}_{12} \mathrm{O}_{2}\right)$, a natural occurring styryllactone. Therefore, it includes (i) the source of GTN and other metabolites; (ii) isolation, purification, and (iii) the molecular mechanisms of actions of GTN, especially the anticancer properties, and summarizes the role of GTN which is crucial for drug design, development, and application in future for well-being of humans.
\end{abstract}

\section{Background}

Cancer continues to be one of the major causes of death worldwide, despite technological advancements in various fields during the last two decades $[1,2]$. Current estimates from the American Cancer Society and from the International Union against Cancer indicate that 12 million cases of cancer were diagnosed last year, accounting for 8.2 million deaths in 2012 worldwide; these numbers are expected to double by 2030 , of which $62 \%$ arise in developing countries (27 million cases with 17 million deaths) [1-4]. As many as $95 \%$ of all cancers are caused by life style (lack of physical activity, tobacco, and alcohol use) and may take as long as 20-30 years to develop [5]. Due to its complex nature, treatment such as surgery, chemotherapy, photodynamic therapy (PDT), and radiation varies according to each type, location, and stage [6].

Medicinal plants are widely used by majority of populations as primary healthcare to cure various diseases and illnesses and have high an economic impact on the world economy $[7,8]$. The increasing interest and scope of the drug of natural origin provides opportunities for its exploration, investigation, and utilization for biological activity [9-11] and particularly considered as cancer preventive or anticarcinogenic agents if they show good availability, low toxicity, suitability for oral application, and a vast variety of mechanisms of their action to prevent or at least delay and inhibit multiple types of cancer [12]. Various bioactive compounds from plant extracts have been experimentally tested to expand the clinical knowledge for its biological effects. As such, natural products have provided a continuous source of novel chemical structures in the development of new drugs and approximately 119 pure compounds isolated from plants are being used as medicine throughout the world.

\section{Plants as Source of Anticancer Agents}

Plants have a long history of use in the treatment of cancer. More than 3000 plant species have been reported to be 
involved in the development of anticancer drugs [13] and $60 \%$ of current anticancer agents have come from natural sources $[14,15]$ which include vinca alkaloids (vincristine, vinblastine, vindesine, vinorelbine), taxanes (paclitaxel, docetaxel), podophyllotoxin and its derivative (etoposide, teniposide), camptothecin and its derivatives (topotecan, irinotecan), anthracyclines (doxorubicin, daunorubicin, epirubicin, idarubicin), and others. Anticancer drugs target several cellular components and activate responses that go from cell repair to cell death $[16,17]$.

\section{Goniothalamus spp.}

Goniothalamus is one of the largest genera of palaeotropical Annonaceae, with over 160 species distributed throughout tropical southeast Asia; the centre of diversity lies in Indochina and Western Malaysia [18]. Only 22 (13.7\%) out of 160 species of Goniothalamus have so far been recognized and investigated out of which only five are medicinal, which are used to treat asthma, rheumatism, fever, malaria, cholera, stomachache, postpartum protective remedy, abortifacient, and insect repellent [19]. Various compounds have been isolated from Goniothalamus species, especially the low molecular weight phenolic styryl-pyrone derivatives as lactonic pharmacophore, quinoline, and isoquinoline alkaloid derivatives and phenanthrene lactones, terpenes, acetogenins, and flavonoids [20-25]. Few styryl-lactones extracted from Goniothalamus are (i) goniothalamin, (ii) altholactone, and (iii) cardiopetalolactone [26].

\section{Bioactive Components of Goniothalamus spp.}

Acetogenins and styryl-lactones from Goniothalamus species have shown to be cytotoxic to different human tumor cell lines [27-29]. Other reported biological properties of some compounds are antifungal, antiplasmodial, antimycobacterial, insecticidal, antimalarial, anti-inflammatory, immunosuppressive, and inhibitor of platelet-activating factor (PAF) receptor binding activities [30, 31]. Currently, 100 styryllactones are available approximately which are either discovered from natural products or made as synthetic analogs. These compounds have been demonstrated to be cytotoxic with preference to kill cancer cells [28, 32-34].

It was reported [26] that GTN as the active constituent of the bark of G. andersonii, G. macrophyllus Miq., and G. malayanus and altholactone was characterized from $G$. arvensis Scheff. and from the G. borneensis Mat-Salleh [35, 36]. Cardiopetalolactone was characterized from the stem bark of G. cardiopetalus Hook.f. \& Thoms. with altholactone, (iv) goniopypyrone, goniothalamin, (v) goniodiol, (vi) goniofufurone, and (vii) goniofupyrone [37, 38]. Goniofufurone, goniopypyrone, goniothalamin, goniodiol, (viii) goniotriol, and (ix) 8-acetylgoniotriol were isolated from the roots of G. griffithii [21-23]. An isomer of altholactone and (x) (+)isoaltholactone was isolated from stem bark of G. malayanus, and from the leaves of G. montanus J. Sincl. and the roots of G. tapis Miq. [39] whereas goniolactones were identified

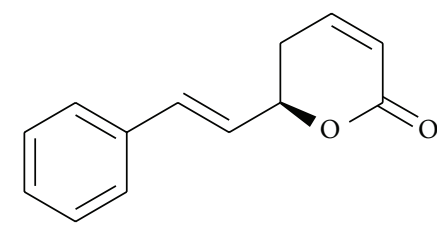

Figure 1: Chemical structure of goniothalamin.

from the roots of G. cheliensis [40]. Digoniodiol, deoxygoniopypyrone A, goniofupyrone, goniothalamin, deoxygoniopypyrone A, gonodiol-8-monoacetate, and gonotriol (xi) were characterized from the aerial parts of G. amuyon, collected in the southern part of Taiwan near the coastal regions [25, 41-45]. The petroleum ether extract of the stem bark of G. sesquipedalis collected in Bangladesh yielded 5-isogoniothalamin oxide [44] and 5-acetyl goniothalamin (xii) was characterized from G. uvaroides King collected in Bangladesh [34] and Chen et al. [46] isolated howiinol A from G. howii Merr. (xiii). The mode of cytotoxic action of styryllactone is described subsequently.

\section{Isolation and Purification of Goniothalamin}

Styryl-lactone GTN (Figure 1) was first isolated in 1972 [26, 47] since then it was subjected to extraction, isolation, and characterization. In most cases, the extracts were prepared by hot and cold extraction methods, that is, Soxhlet and percolation techniques, respectively. The crude methanol extracts were obtained by removing the solvent under reduced pressure and the yields were calculated based on dry weight. Bioactive compounds were isolated using various chromatographic techniques (VLC, column chromatography, Prep-TLC, etc.). The structures of bioactive compounds were also elucidated using spectroscopic techniques (1D, 2D NMR spectroscopy, FTIR, UV, mass spectrometry, etc.). Chromatographic fingerprint (HPLC) and spectrophotometric fingerprinting (ATR-FTIR) analyses with reference markers were also carried out on the plant extract. Briefly, the herbs were ground to powder, extracted in $\mathrm{MeOH}$ by ultrasonication for $30 \mathrm{~min}$, and filtered. The chromatographic system consists of a HPLC equipped with a secondary pump, a diode-array detector, an autosampler, and a column compartment, a C18 column packed with $5 \mu \mathrm{m}$ diameter particles. A suitable solvent system was used for extraction process, for example, trifluoroacetic acid and acetonitrile was used with a linear gradient elution. Analytical technique using HPLC-DAD was developed and used to quantify the bioactive components of each extract as marker compounds. Preparation of the herb and the HPLC setup varied as per individual laboratory set up $[48,49]$.

\section{Synthesis of Goniothalamin}

Due to its diverse pharmacological properties, GTN gained huge interest from researchers because several successful approaches have been adopted for its synthesis [50-54]. The absolute configuration in the pyran-2-one 


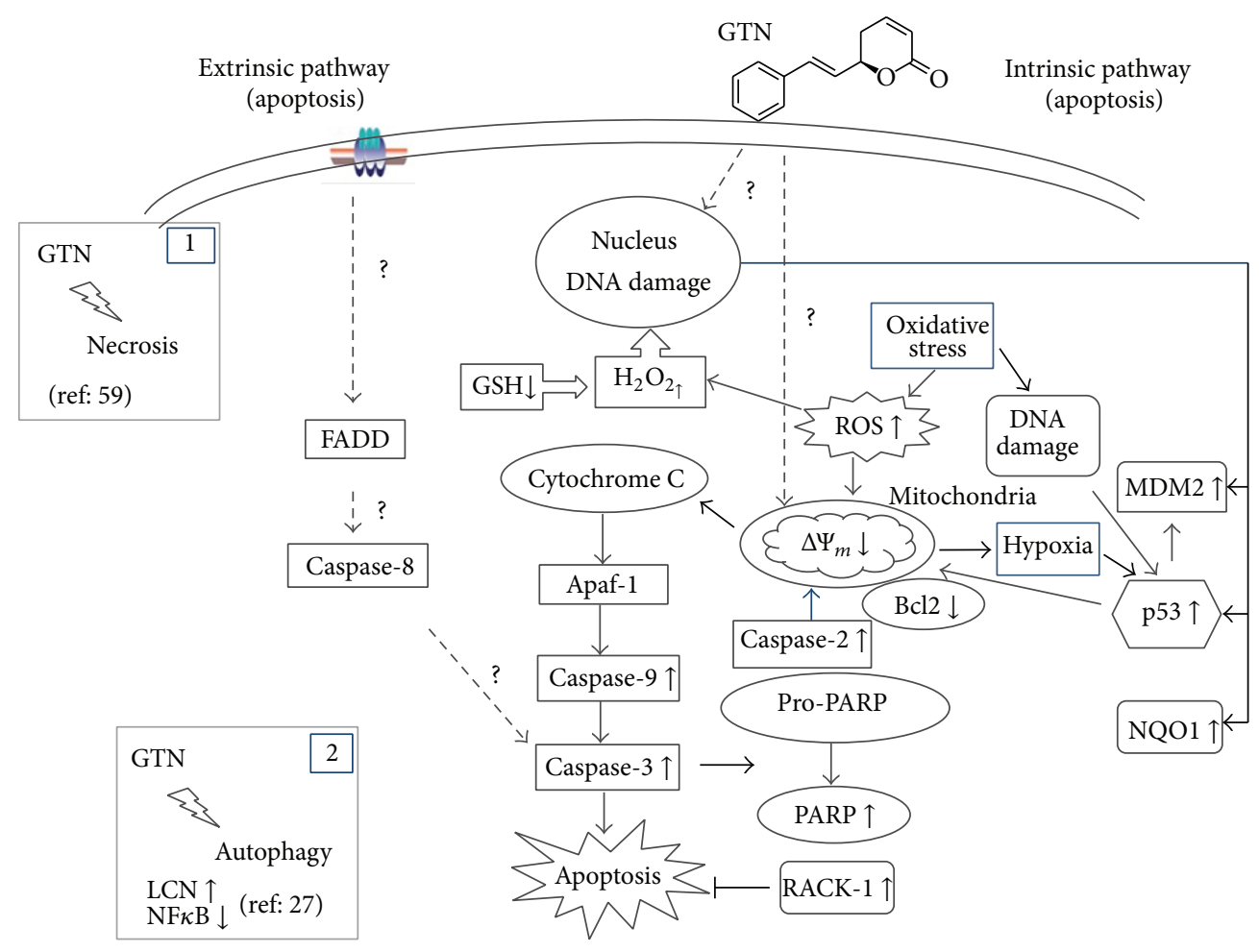

FIGURE 2: Schematic representation of mechanism of action of goniothalamin (GTN) in cancer cells. GTN mostly induces apoptosis either by DNA damage from oxidative stress where GTN decreases GSH level and increases ROS production or direct effect on DNA. Alternatively, GTN may directly affect mitochondria leading to ROS production. The GTN induced cellular stress response leads to the upregulation of p53 as an initial signal for apoptosis. Once activated, the p53 protein can directly or via processing caspase-2 trigger the release of cytochrome $c$ without loss of membrane potential. This is followed by caspase- 9 and caspase-3 subsequently. GTN may also act directly on mitochondria or induce the upregulation of Fas/FasL but that needs to be further investigated.

moiety has generally been secured from chiral starting material, asymmetric allylboration of aldehydes with $\beta$ allyldiisopinocampehylborane $[50,55,56]$, or through asymmetric reduction using enzymes or microorganisms [51, 53, 54, 57-61]. De Fátima and Pilli [51] reported the syntheses of GTN via catalytic asymmetric allylation of $\alpha$ benzyloxyacetaldehyde, followed by ring-closing metathesis and Wittig olefination, and via catalytic asymmetric allylation of trans-cinnamaldehyde, followed by ring-closing metathesis [62]. Gruttadauria et al. [54] along with coworkers reported that the high-yielding three-step synthesis of GTN involves an enzymatic kinetic resolution in the presence of vinyl acrylate followed by ring-closing metathesis [54]. GTN has been synthesized by lipase catalyzed resolution of (1E)-1phenylhexa-1, 5-dien-3-ol using vinyl acrylate as acyl donor followed by ring-closing metathesis of the formed (1R)-1-[(E)2-phenylvinyl] but-3-enyl acrylate. The unreacted alcohol from the resolution, (1E, 3S)-1-phenylhexa-1, 5-dien-3-ol, was esterified nonenzymatically and used for synthesis of GTN [53]. Das et al. [63] reported that the stereo selective total synthesis of GTN is achieved via a common intermediate. The synthesis employed the reduction of a propargyl ketone and olefin cross-metathesis as the key steps [63]. Fournier et al. showed that the diastereoselective [2+2]-cycloaddition of $\beta$-silyloxy aldehydes with trimethylsilylketene followed by
HF-induced translactonization is a useful short method for the efficient synthesis of $\alpha, \beta$-unsaturated- $\delta$-lactones [64].

\section{Mechanism of Action}

7.1. Cytotoxic Activity against Cancer Cells. GTN, a simple styryl-lactone has significant potential in the development of a cancer drug as it has been reported to possess a wide range of biological activities (Figure 2) including anticancer [34], anti-inflammatory [65], immunosuppressive, and apoptotic effects [21, 24, 28, 66-68]. GTN had been able to induce cytotoxicity in a variety of cancer cell lines including vascular smooth muscle cells (VSMCs), Chinese hamster ovary cells, renal cells [69-71], hepatoblastoma [72, 73], gastric, kidney cells, breast carcinomas, leukemia, Jurkat cells $[67,69,74-$ 84], hepatocellular carcinoma [85], lung cancer cells [86], oral cancer cells $[87,88]$, and HeLa cells $[89,90]$ but sparing the normal cells including blood cells [83].

Besides the above, GTN has been proved to be only cytotoxic to ovarian cancer cell line (Caov-3) without causing cell death in normal kidney cell (MDBK) when compared to tamoxifen or taxol treated cells [32]. In addition, GTN showed lower toxicity to normal liver Chang cell line as compared to doxorubicin (known chemotherapeutic drug) $[72,73]$. On the other hand a study by [75] reported the 
antiproliferative activity of GTN in some solid tumor experimental model with no evidence of toxic effects in the animals after single and repeated doses.

7.2. Induction of Apoptosis. GTN initially induces DNA damage which subsequently leads to cytotoxicity primarily via apoptosis in VSMCs [78]. This finding indicates that apoptosis that had occurred on this method was previously described by Cohen [91] and Ren et al. [92] and others on HeLa cells $[92,93]$. The above findings were confronted by Alabsi et al. [90] that GTN stimulate DNA fragmentation, a characteristic feature of apoptosis in HeLa cell line at 24, 48, and $72 \mathrm{~h}$ after treatment. DNA fragments reveal, upon agarose gel electrophoresis, a distinctive ladder pattern consisting of multiples of an approximately 180 base pairs subunit. DNA ladder formation is observed only when the extent of oligonucleosomal cleavage is prominent. Alabsi et al. [90] suggested that internucleosomal cleavage of DNA is likely to be in the later phase of apoptotic process [91, 94, 95]. Some evidence has indicated that GTN exposure can alter the membrane properties [67].

Apoptosis can be either caspase-dependent or caspaseindependent $[96,97]$. However, the mechanism of caspaseindependent apoptosis was still poorly understood until recently. Caspase plays important roles in execution of apoptosis through either extrinsic or intrinsic pathways [33]. The ability of GTN to induce apoptosis via caspase3 activation against hepatoblastoma (HepG2) cells, whereas in human Jurkat T-cells both caspases 3 and 7 activation is involved, which is totally absent in normal Chang liver cells [24] and caspases 3 and 7 in human Jurkat T-cells [81]. In this study, HepG2 and Chang cells were treated with GTN for $72 \mathrm{~h}$ and analysed by TUNEL and AnnexinV/PI staining. Furthermore, the postmitochondrial caspase3 was quantified using ELISA and alteration of cellular membrane integrity and cleavage of DNA were also observed. On the other hand, postmitochondrial caspase- 3 activity was significantly elevated in HepG2 cells treated with GTN after $72 \mathrm{~h}$. These findings suggest that GTN induced apoptosis on HepG2 liver cancer cells via induction of caspase-3 with less sensitivity on the cell line of Chang cells. Besides the above, it was also shown that the executioner caspase-3/7/9 activity, not initiator caspase-8, was increased in low level, less than onefold at 6 hours and 24 hours of treatment with GTN as compared to untreated cells [90]. Previous study also reported that the sequential activation of caspase- 9 but not caspase- 8 leading to the downstream caspase- 3 cleavage was observed in GTN-treated coronary artery smooth muscle cells (CASMCs) [79].

It has also been reported that GTN induced apoptosis in HL-60 and Jurkat cells via mitochondrial pathway [67, 82]. Thus, these findings suggested the insignificant role of caspase- 8 as an initiator caspase. Caspase- 8 is not essential in GTN induced apoptosis in HeLa cells. In order to rule out the possibility of caspase-8 involvement in GTN induced apoptosis, a detailed appropriate study is still required. de Fátima et al. [70] reported that R-GTN and S-GTN markedly downregulated $\mathrm{Bcl} 2$, an antiapoptotic protein, and also induced PARP cleavage by causing apoptosis in renal cancer cells. In this study, authors have also reported interestingly that S-GTN enhanced the expression of LC3; a typical marker of autophagy and NFkappaB was downregulated in S-GTNtreated cells. Overall, these results indicate that the antiproliferative activity of the two enantiomers of GTN on renal cancer cells involved distinct signaling pathways, apoptosis, and autophagy as dominant responses towards R-GTN and SGTN, respectively. Also, it was reported that GTN treatment induces cell cycle arrest at G2/M level [33] and concentration dependent necrotic type of cell death [74]. However, most of the studies have reported that GTN induced cell death predominantly occurred through apoptosis mode only.

It has been reported that cytotoxic stress either from DNA damage or mitochondrial impairment leads to apoptosis via the intrinsic pathway $[78,98]$. The intrinsic pathway involves the release of proapoptotic proteins including cytochrome $c$ from the inner membrane of mitochondria to the cytosol leading to activation of caspase-9 [99]. Most of the styryllactones including GTN and altholactone induce oxidative stress in MDA-MD-231 breast cancer cells, and Jurkat and HL-60 leukemic cells leading to apoptosis [40, 92, 100]. Although previous work has demonstrated that GTN induces DNA damage in CASMCs, which subsequently leads to apoptosis induction [101] and this study hypothesizes that GTN-induced oxidative stress and DNA damage resulted in p53 upregulation which was stabilized by NQO1 leading to caspase-2-dependent mitochondrial-mediated apoptotic pathway. However, the mechanisms of oxidative stress induced by styryl-lactones have not been unraveled. Numerous studies have demonstrated that the oncoprotein $\mathrm{Bcl}-2$ can inhibit apoptosis by inhibiting the release of cytochrome $c$ and can also modulate oxidant induced apoptosis [102]. Since the discovery of the caspase- 9 apoptosome complex [103], more recent studies have shown that the initiator caspase-2 also forms a complex with RAIDD, a death receptor molecule, and the p53 inducible death domain PIDD forming a PIDDosome complex [104]. Importantly, caspase-2 has been demonstrated in a variety of cell lines to be activated upstream of mitochondria in genotoxin-induced apoptosis. Cleavage of the proapoptotic Bcl-2 family member Bid by caspase-2 has been shown to be required for cytochrome $c$ release suggesting a potentially crucial role for caspase-2.

Although a large body of evidence suggests that various plant metabolites exterted their potentials against many cancer types through their unique mechanism of action for example, vincristine inhibits microtubule assembly, inducing tubulin self-association into coiled spiral aggregates [105]. Etoposide, a topoisomerase II inhibitor [106, 107] causes the stabilization of the clevable DNA- topoisomerase II covalent complexes, preventing subsequent DNA religation and stimulate enzyme-linked DNA breaks [108]. The taxanes paclitaxel and docetaxel has shown antitumor activity against breast, ovarian, and other tumor types in the clinic trial. Paclitaxel stabilizes microtubules and leads to mitotic arrest [109]. In addition, the camptothecin derivatives irinotecan and topotecan have shown significant antitumor activity against colorectal and ovarian cancer, respectively [100, 110], by inhibiting topoisomerase I [111]. Despite the above development, the unequal distribution of cancer burden 
TABLE 1: Mechanism of action of Goniothalamin (GTN) in various cancer cells and their molecular effects.

\begin{tabular}{|c|c|c|c|c|c|}
\hline S. no & $\begin{array}{l}\text { Cell line } \\
\text { (in vitro) }\end{array}$ & $\begin{array}{l}\text { Animals } \\
\text { (in vivo) }\end{array}$ & Mode of cell death & Molecular targets/effects & References \\
\hline 1 & 786-0 (renal cells) & - & Cytotoxicity/apoptosis & NOS $\uparrow / B C L 2 \downarrow$ & {$[27,70]$} \\
\hline 2 & 786-0 (renal cells) & - & Cytotoxicity/autophagy & $\mathrm{LC} 3 \uparrow / \mathrm{NF} \kappa \mathrm{B} \downarrow$ & [27] \\
\hline 3 & Jurkat T-cells & - & Cytotoxicity/apoptosis & $\begin{array}{c}\text { Caspases } 3 \text { and } 7 \uparrow \text {, oxidative stress, } \\
\text { DNA damage } \\
\text { RACK } 1 \uparrow\end{array}$ & $\begin{array}{c}{[81,82]} \\
{[80]} \\
{[70]}\end{array}$ \\
\hline 4 & $\begin{array}{l}\text { HepG2 (hepatoblastoma) } \\
\text { Chang (normal cells) }\end{array}$ & - & $\begin{array}{l}\text { Cytotoxicity/apoptosis } \\
\text { No toxicity }\end{array}$ & $\begin{array}{c}\text { Caspase- } 3 \uparrow \\
\text { Sparing normal cells } \\
\end{array}$ & $\begin{array}{c}{[72,73]} \\
{[72]}\end{array}$ \\
\hline 5 & HCC (hepatocellular carcinoma) & - & Cytotoxicity/apoptosis & ROS $\uparrow$ & {$[85]$} \\
\hline 6 & $\begin{array}{c}\text { Caov-3 (ovarian) } \\
\text { Caov-3 (ovarian) } \\
\text { MDBK (normal kidney cells) }\end{array}$ & - & $\begin{array}{l}\text { Cytotoxicity/apoptosis } \\
\text { Antiproliferative } \\
\text { No toxicity }\end{array}$ & $\begin{array}{c}\text { Caspase- } 3 \uparrow \\
\text { bcl- } 2 \downarrow \text { and bax } \uparrow \\
\text { Sparing normal cells }\end{array}$ & $\begin{array}{l}{[32]} \\
{[77]} \\
{[80]}\end{array}$ \\
\hline 7 & $\begin{array}{l}\text { MCF-7, T47D, MDA-MB-231 } \\
\text { (breast cancer) }\end{array}$ & - & Cytotoxicity/apoptosis & $\begin{array}{c}\text { Cell cycle arrest/modulating redox } \\
\text { status }\end{array}$ & {$[33,89]$} \\
\hline 8 & MCF-7 (breast cancer) & - & Cytotoxicity/necrosis & Membrane integrity loss & {$[74]$} \\
\hline 9 & $\begin{array}{c}\text { COR-L23 (large } \\
\text { cell lung carcinoma) }\end{array}$ & - & Cytotoxicity & $\begin{array}{l}\text { Good cytotoxic compound to } \\
\text { cancer cells }\end{array}$ & {$[68]$} \\
\hline 10 & $\begin{array}{l}\text { NCI-H460 (human nonsmall cell } \\
\text { lung cancer cells) }\end{array}$ & - & Cytotoxicity/apoptosis & DNA damage & {$[86]$} \\
\hline 11 & Ca9-22 (oral cancer) & - & Cytotoxicity/apoptosis & DNA damage, $\operatorname{ROS} \uparrow, \Delta \Psi \downarrow$ & {$[88]$} \\
\hline 12 & U251 (glioma) & - & Antiproliferative & $\begin{array}{l}\text { Good cytotoxic compound to } \\
\text { cancer cells }\end{array}$ & {$[65]$} \\
\hline 13 & OVCAR-03 (ovarian) & - & Antiproliferative & $\begin{array}{l}\text { Good cytotoxic compound to } \\
\text { cancer cells }\end{array}$ & {$[65]$} \\
\hline 14 & PC-3 (prostate) & - & Antiproliferative & $\begin{array}{l}\text { Good cytotoxic compound to } \\
\text { cancer cells }\end{array}$ & {$[65]$} \\
\hline 15 & W7.2 T-cells & - & Cytotoxicity/apoptosis & DNA damage, RACK1 $\uparrow$ & {$[70]$} \\
\hline 16 & NCI-460 (lung, nonsmall cells) & - & Antiproliferative & $\begin{array}{l}\text { Good cytotoxic compound to } \\
\text { cancer cells }\end{array}$ & {$[65]$} \\
\hline 17 & NSCLC lung cancer & - & Cytotoxicity/apoptosis & $\begin{array}{c}\text { DNA damage, } \\
\text { MMP-2 and MMP-9 } \downarrow \\
\end{array}$ & {$[87]$} \\
\hline 18 & UACC-62 (melanoma) & - & Antiproliferative & $\begin{array}{l}\text { Good cytotoxic compound to } \\
\text { cancer cells }\end{array}$ & {$[65]$} \\
\hline 19 & HL-60 (leukemia) & - & Genotoxicity/apoptosis & $\Psi \downarrow$, caspase- $9 \uparrow$ & $\begin{array}{l}{[67,80]} \\
{[84,101]} \\
\end{array}$ \\
\hline 20 & U937 (lymphoma) & - & Cytotoxicity/apoptosis & 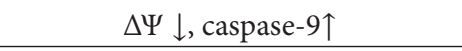 & {$[84]$} \\
\hline 21 & $\begin{array}{l}\text { CASMC (coronary artery } \\
\text { smooth muscle cells) }\end{array}$ & - & Cytotoxicity/apoptosis & Caspase- $2 \uparrow, \mathrm{p} 53 \uparrow$ & {$[78,79]$} \\
\hline 22 & HeLa (cervical) & - & $\begin{array}{l}\text { Cytotoxicity } \\
\text { apoptosis }\end{array}$ & $\begin{array}{l}\text { Good cytotoxic compound to } \\
\text { cancer cells } \\
\text { DNA damage, caspase-9 } \uparrow \\
\end{array}$ & $\begin{array}{c}{[80-82]} \\
{[90]}\end{array}$ \\
\hline 23 & HGC-27 (gastric) & - & Cytotoxicity & $\begin{array}{l}\text { Good cytotoxic compound to } \\
\text { cancer cells }\end{array}$ & {$[74,80-82]$} \\
\hline 24 & 768-0 (kidney) & - & Cytotoxicity & $\begin{array}{l}\text { Good cytotoxic compound to } \\
\text { cancer cells }\end{array}$ & {$[80-82]$} \\
\hline 25 & $\begin{array}{l}\text { HT-29 (colon) } \\
\text { LS174T (colon) }\end{array}$ & - & Cytotoxicity/apoptosis & Cell cycle arrest at S-phase & $\begin{array}{l}{[89]} \\
{[68]}\end{array}$ \\
\hline 26 & $\begin{array}{l}\text { 3T3 (normal fibroblast) } \\
\text { ST3 fibroblast }\end{array}$ & - & $\begin{array}{l}\text { No toxicity } \\
\text { Cytotoxicity }\end{array}$ & $\begin{array}{c}\text { Sparing normal cells } \\
\text { Kills MMP1 expressing cells }\end{array}$ & $\begin{array}{l}{[89]} \\
{[68]} \\
\end{array}$ \\
\hline 27 & PANC-1 (pancreatic cancer) & - & Cytotoxicity/necrosis & Loss of cell membrane integrity & {$[74]$} \\
\hline 28 & CHO (Chinese hamster ovary) & - & Genotoxicity & Causing damage to DNA & {$[69]$} \\
\hline 29 & $\begin{array}{c}\text { K562 (chronic myelogenous } \\
\text { leukemia) }\end{array}$ & - & $\begin{array}{c}\text { Cytotoxic and } \\
\text { anti-inflammatory }\end{array}$ & $\mathrm{NF}-\kappa \mathrm{B} \downarrow$ & {$[83]$} \\
\hline
\end{tabular}


TABLe 1: Continued.

\begin{tabular}{lcccc}
\hline S. no & $\begin{array}{c}\text { Cell line } \\
\text { (in vitro) }\end{array}$ & $\begin{array}{c}\text { Animals } \\
\text { (in vivo) }\end{array}$ & Mode of cell death & Molecular targets/effects \\
\hline 30 & Platelets (rabbits) & - & Inhibitory & Platelet activating factor binding \\
\hline 31 & Ehrlich tumor cells & $\begin{array}{c}\text { Balb/C } \\
\text { mice }\end{array}$ & Cytotoxicity & Tumor regression \\
\hline 32 & Blood and serum parameters & $\begin{array}{c}\text { Long } \\
\text { Evans rats }\end{array}$ & Cytotoxicity & $\begin{array}{c}\text { Biochemical/hematology and } \\
\text { histopathology evaluation }\end{array}$ \\
\hline
\end{tabular}

between the developing and developed world is still largely looking for a better and safer anticancer compound for human use. Based on the data obtained from both in vitro cell culture and few in vivo animal models, GTN has demonstrated its potential against cancers and proven its insignificant effects on normal cells (Table 1). Taken together, undoubtedly GTN is emerging as promising agent in anticancer drug development with potential applications in cancer chemotherapy.

\section{Conclusion}

In conclusion, styryl-lactones are a group of secondary metabolites ubiquitous in the genus Goniothalamus that has demonstrated to possess interesting biological properties. These findings revealed that Goniothalamus plants do possess anticancer activity in a selective manner towards several tumor cell lines and initiate them to undergo different mode of cell death mainly apoptosis. Although the anticancer activity of the potential biomarker of this herbal plant, GTN on multiple cancer cells was through its regulation on cancer cell cycle and apoptosis induction mediated via oxidative stress and caspases activation and the antimetastatic and antiangiogenesis effects observed in GTN treated cells and animal, indicate its potential in inhibiting the development of secondary tumour. Further investigations into the mechanism of anticarcinogenic, antimetastatic, antiangiogenesis, and apoptotic regulation properties of GTN against various in vivo cancer models are still required. This may create an opportunity for the compound not only to be designed and developed as anticancer agent, but also to be used as an adjuvant or immunomodulators for combination chemotherapy against cancer. However, the preliminary in vitro data is insufficient and less convincing due to its limitation as most of the experiments are done in an ex vivo environment outside an animal or human body. Thus, more in vivo studies using various experimental cancer animal models are needed to determine the pharmacological and toxicological data as well as antitumour effect of GTN. Due to its diverse pharmacological properties, this compound gained huge interest among researchers that lead to the cost effective approaches for its synthesis; hence, this activity will further strengthen the efforts to identify more pathways and therapeutic action of this compound before it enters into the next phase of development. Overall, this compound provides information on the safe use and effectiveness that is crucial for drug design, development, and application in future for well-being of human.

\section{Conflict of Interests}

The authors declare that there is no conflict of interests regarding the publication of this paper.

\section{References}

[1] B. W. Stewart and C. P. Wild, Eds., World Cancer Report 2014, International Agency for Research on Cancer, Lyon, France, 2014.

[2] "SEER Cancer Statistics Review 1975-2010, National Cancer Institute, Cancer Facts and Figures 2013, American Cancer Society (ACS)," IARC, Globocan, Atlanta, Ga, USA, 2012.

[3] N. W. Kim, M. A. Piatyszek, K. R. Prowse et al., "Specific association of human telomerase activity with immortal cells and cancer," Science, vol. 266, no. 5193, pp. 2011-2015, 1994.

[4] C. de Martel, J. Ferlay, S. Franceschi et al., "Global burden of cancers attributable to infections in 2008: a review and synthetic analysis," The Lancet Oncology, vol. 13, no. 6, pp. 607-615, 2012.

[5] H. C. Pitot, Fundamentals of Oncology (Hardcover, Revised), 2002.

[6] M. Ali-Seyed, R. Bhuvaneswari, K. C. Soo, and M. Olivo, "Photolon-Photosensitization induces apoptosis via ROSmediated cross-talk between mitochondria and lysosomes," International Journal of Oncology, vol. 39, no. 4, pp. 821-831, 2011.

[7] J. Mann, "Natural products in cancer chemotherapy: past, present and future," Nature Reviews Cancer, vol. 2, no. 2, pp. 143148, 2002.

[8] A. E. Bauman, "Updating the evidence that physical activity is good for health: an epidemiological review 2000-2003," Journal of Science and Medicine in Sport, vol. 7, no. 1, pp. 6-19, 2004.

[9] W. C. Willett, "Diet and health: what should we eat?" Science, vol. 264, no. 5158, pp. 532-537, 1994.

[10] P. K. T. Pang, J. J. Shan, and K. W. Chiu, "Pharmacological standardization of herbal extracts," in USPTO Patent Full-Text and Image Database, USPTO, Ed., CV Technologies, Jupiter, Fla, USA, 2000.

[11] H. O. Edeoga, D. E. Okwu, and B. O. Mbaebie, "Phytochemical constituents of some Nigerian medicinal plants," African Journal of Biotechnology, vol. 4, no. 7, pp. 685-688, 2005.

[12] M. Pan and C. Ho, "Chemopreventive effects of natural dietary compounds on cancer development," Chemical Society Reviews, vol. 37, no. 11, pp. 2558-2574, 2008.

[13] M. Shoeb, "Anticancer agents from medicinal plants," Bangladesh Journal of Pharmacology, vol. 1, pp. 35-41, 2006.

[14] G. M. Cragg and D. J. Newman, "Plants as a source of anticancer agents," Journal of Ethnopharmacology, vol. 100, no. 1-2, pp. 72-79, 2005. 
[15] C. Bailly, "Ready for a comeback of natural products in oncology," Biochemical Pharmacology, vol. 77, no. 9, pp. 14471457, 2009.

[16] G. M. Cragg, D. J. Newman, and R. B. Weiss, "Coral reefs, forests, and thermal vents: the worldwide exploration of nature for novel antitumor agents," Seminars in Oncology, vol. 24, no. 2, pp. 156-163, 1997.

[17] D. J. Newman and G. M. Cragg, "Natural products as sources of new drugs over the last 25 years," Journal of Natural Products, vol. 70, no. 3, pp. 461-477, 2007.

[18] R. M. K. Saunders, "A synopsis of Goniothalamus species (Annonaceae) in Peninsular Malaysia, with a description of a new species," Botanical Journal of the Linnean Society, vol. 142, no. 3, pp. 321-339, 2003.

[19] I. H. Burkill, A Dictionary of the Economic Products of the Malay Peninsula, Ministry of Agriculture and Cooperative, Kuala Lumpur, Malaysia, 1966.

[20] Y. J. Zhang, M. Kong, R. Y. Chen, and D. Q. Yu, "Alkaloids from the roots of Goniothalamus griffithii," Journal of Natural Products, vol. 62, no. 7, pp. 1050-1052, 1999.

[21] Y. J. Zhang, G. X. Zhou, R. Y. Chen, and D. Q. Yu, "Styryllactones from the rhizomes of Goniothalamus griffithii," Journal of Asian Natural Products Research, vol. 1, no. 3, pp. 189-197, 1999.

[22] V. Seidel, F. Bailleul, and P. G. Waterman, "(Rel)-1 $\beta, 2 \alpha$-di-(2,4dihydroxy-6-methoxybenzoyl)-3 $\beta, 4 \alpha$-di-(4-methoxyphenyl)cyclobutane and other flavonoids from the aerial parts of Goniothalamus gardneri and Goniothalamus thwaitesii," Phytochemistry, vol. 55, no. 5, pp. 439-446, 2000.

[23] Q. Mu, W. D. Tang, R. Y. Liu et al., "Constituents from the Stems of Goniothalamus griffithii," Planta Medica, vol. 69, no. 9, pp. 826-830, 2003.

[24] S. Wang, S. J. Dai, R. Y. Chen, S. S. Yu, and D. Q. Yu, "Two new styryllactones from Goniothalamus cheliensis," Chinese Chemical Letters, vol. 14, no. 5, pp. 487-488, 2003.

[25] Y. H. Lan, F. R. Chang, C. C. Liaw, C. C. Wu, M. Y. Chiang, and Y. C. Wu, "Digoniodiol, deoxygoniopypyrone A, and goniofupyrone A: three new styryllactones from Goniothalamus amuyon," Planta Medica, vol. 71, no. 2, pp. 153-159, 2005.

[26] K. Jewers, J. B. Davis, J. Dougan et al., "Goniothalamin and its distribution in four Goniothalamus species," Phytochemistry, vol. 11, no. 6, pp. 2025-2030, 1972.

[27] A. de Fátima, L. K. Kohn, J. E. de Carvalho, and R. A. Pilli, "Cytotoxic activity of (S)-goniothalamin and analogues against human cancer cells," Bioorganic and Medicinal Chemistry, vol. 14, no. 3, pp. 622-631, 2006.

[28] Â. de Fátima, L. V. Modolo, L. S. Conegero et al., "Styryl lactones and their derivatives: biological activities, mechanisms of action and potential leads for drug design," Current Medicinal Chemistry, vol. 13, no. 28, pp. 3371-3384, 2006.

[29] Z. Tian, S. Chen, Y. Zhang et al., "The cytotoxicity of naturally occurring styryl lactones," Phytomedicine, vol. 13, no. 3, pp. 181186, 2006.

[30] J. B. Calixto, M. M. Campos, M. F. Otuki, and A. R. S. Santos, "Anti-inflammatory compounds of plant origin. Part II. Modulation of pro-inflammatory cytokines, chemokines and adhesion molecules," Planta Medica, vol. 70, no. 2, pp. 93-103, 2004.

[31] B. A. Moharam, I. Jantan, J. Jalil, and F. Ahmad, "Inhibitory effect of compounds from Goniothalamus tapis Miq. and Goniothalamus uvaroides King on platelet-activating factor receptor binding," Phytotherapy Research, vol. 26, no. 5, pp. 687-691, 2012.
[32] T. P. Lin and A. H. L. Pihie, "Goniothalamin-induced apoptosis in human ovarian cancer cell line," Borneo Science, vol. 14, pp. 9-14, 2003.

[33] W. Chen, C. Wu, Y. Lan, F. Chang, C. Teng, and Y. Wu, "Goniothalamin induces cell cycle-specific apoptosis by modulating the redox status in MDA-MB-231 cells," European Journal of Pharmacology, vol. 522, no. 1-3, pp. 20-29, 2005.

[34] M. A. Blázquez, A. M. Bermejo, Z. P. Carmen, and D. Cortes, "Styryl-lactones from Goniothalamus species-a review," Phytochemical Analysis, vol. 10, no. 4, pp. 161-170, 1999.

[35] A. Bermejo, M. A. Blázquez, K. S. Rao, and D. Cortes, "Styrylpyrones from Goniothalamus arvensis," Phytochemistry, vol. 47, no. 7, pp. 1375-1380, 1998.

[36] S.-G. Cao, X.-H. Wu, K.-Y. Sim, B. K. H. Tan, J. T. Pereira, and S. Goh, "Styryl-lactone derivatives and alkaloids from Goniothalamus borneenis (Annonaceae)," Tetrahedron, vol. 54, no. 10 , pp. 2143-2148, 1998.

[37] A. Hisham, A. Harassi, W. Shuaily, S. Echigo, and Y. Fujimoto, "Cardiopetalolactone: a novel styryllactone from G. cardiopetalus," Tetrahedron, vol. 56, no. 51, pp. 9985-9989, 2000.

[38] A. Hisham, M. Toubi, W. Shuaily, M. D. A. Bai, and Y. Fujimoto, "Cardiobutanolide, a styryllactone from Goniothalamus cardiopetalus," Phytochemistry, vol. 62, no. 4, pp. 597-600, 2003.

[39] S. M. Colegate, L. B. Din, A. Latiff et al., "(+)-Isoaltholactone: a furanopyrone isolated from Goniothalamus species," Phytochemistry, vol. 29, no. 5, pp. 1701-1704, 1990.

[40] S. Wang, Y. J. Zhang, R. Y. Chen, and D. Q. Yu, "Goniolactones A-F, six new styrylpyrone derivatives from the roots of Goniothalamus cheliensis," Journal of Natural Products, vol. 65, no. 6, pp. 835-841, 2002.

[41] F. B. Ahmad, W. A. Tukol, S. Omar, and A. M. Sharif, "5-Acetyl goniothalamin, a styryl dihydropyrone from G. uvaroides," Phytochemistry, vol. 30, no. 7, pp. 2430-2431, 1991.

[42] Y. Wu, C. Duh, F. Chang et al., "The crystal structure and cytotoxicity of goniodiol-7-monoacetate from G. amuyon," Journal of Natural Products, vol. 54, no. 4, pp. 1077-1081, 1991.

[43] Y. Wu, F. Chang, C. Duh, S. Wang, and T. Wu, "Cytotoxic styrylpyrones of Goniothalamus amuyon," Phytochemistry, vol. 31, no. 8, pp. 2851-2853, 1992.

[44] C. M. Hasan, M. Y. Mia, M. A. Rashid, and J. D. Connolly, "5Acetoxyisogoniothalamin oxide, an epoxystyryl lactone from Goniothalamus sesquipedalis," Phytochemistry, vol. 37, no. 6, pp. 1763-1764, 1994.

[45] Y. Lan, F. Chang, J. Yu et al., "Cytotoxic styrylpyrones from Goniothalamus amuyon," Journal of Natural Products, vol. 66, no. 4, pp. 487-490, 2003.

[46] R. Chen, D. Yu, L. Ma, F. Wu, and W. Song, "The chemical constituents of Goniothalamus howii Merr," Yao Xue Xue Bao, vol. 33, no. 6, pp. 453-456, 1998.

[47] M. A. Mosaddik and M. E. Haque, "Toxicological evaluation of goniothalamin i isolated from bryonopsis laciniosa linn, in rats," Pharmacy and Pharmacology Communications, vol. 5, no. 6, pp. 411-413, 1999.

[48] S. A. El-Zayat, M. S. M. Nassar, F. T. El-Hissy, F. F. Abdel-Motaal, and S. Ito, "Mycoflora associated with Hyoscyamus muticus growing under an extremely arid desert environment (Aswan region, Egypt)," Journal of Basic Microbiology, vol. 48, no. 2, pp. 82-92, 2008.

[49] J. Pospísil and I. E. Markó, "Total synthesis of (R)-(+)goniothalamin and (R)-(+)-goniothalamin oxide: first application of the sulfoxide-modified Julia olefination in total synthesis," Tetrahedron Letters, vol. 47, no. 33, pp. 5933-5937, 2006. 
[50] P. V. Ramachandran, M. V. R. Reddy, and H. C. Brown, "Asymmetric synthesis of goniothalamin, hexadecanolide, massoia lactone, and parasorbic acid via sequential allylborationesterification ring-closing metathesis reactions," Tetrahedron Letters, vol. 41, no. 5, pp. 583-586, 2000.

[51] Â. De Fátima and R. A. Pilli, "Enantioselective approach to the asymmetric synthesis of (6R)-hydroxymethyl-5,6-dihydro-2Hpyran-2-one. A formal synthesis of $(R)$-argentilactone and total synthesis of $(R)$-goniothalamin," Arkivoc, vol. 2003, no. 10, pp. 118-126, 2003.

[52] M. Tsubuki, K. Kanal, and T. Honda, "Enantioselective synthesis of 6-substituted 5,6-dihydro- $\alpha$-pyranones, (+)-goniothalamin and (-)-argentilactone," Heterocycles, vol. 35, no. 1, pp. 281-288, 1993.

[53] E. Sundby, L. Perk, T. Anthonsen, A. J. Aasen, and T. V. Hansen, "Synthesis of (+)-goniothalamin and its enantiomer by combination of lipase catalyzed resolution and alkene metathesis," Tetrahedron, vol. 60, no. 3, pp. 521-524, 2004.

[54] M. Gruttadauria, P. Lo Meo, and R. Noto, "Short and efficient chemoenzymatic synthesis of goniothalamin," Tetrahedron Letters, vol. 45, no. 1, pp. 83-85, 2004.

[55] H. C. Brown and P. K. Jadhav, "Asymmetric carbon-carbon bond formation via $\beta$-allyldiisopinocampheylborane. Simple synthesis of secondary homoallylic alcohols with excellent enantiomeric purities," Journal of the American Chemical Society, vol. 105, no. 7, pp. 2092-2093, 1983.

[56] H. C. Brown and P. Veeraraghavan Ramachandran, "Versatile $\alpha$-pinene-based borane reagents for asymmetric syntheses," Journal of Organometallic Chemistry, vol. 500, no. 1-2, pp. 1-19, 1995.

[57] B. O'Connor and G. Just, "Syntheses of argentilactone 11 and Goniothalamin 15," Tetrahedron Letters, vol. 27, no. 43, pp. 52015202, 1986.

[58] S. S. Rahman, B. J. Wakefield, S. M. Roberts, and M. D. Dowle, "Intramolecular nucleophilic addition to photochemically generated ketenes as a versatile route to lactones and lactams; synthesis of a mosquito pheromone, goniothalamin, argentilactone, and the Streptomyces L-factor," Journal of the Chemical Society, Chemical Communications, no. 5, pp. 303304, 1989.

[59] F. Bennett and D. W. Knight, "An alternative approach to mevinic acid analogues from methyl (3R)-3-hydroxy-5hexenoate and an extension to rational syntheses of (+)(6R)-goniothalamin and its non-natural (-)-(6S)-enantiomer," Tetrahedron Letters, vol. 29, no. 36, pp. 4625-4628, 1988.

[60] B. Henkel, A. Kunath, and H. Schick, "Enzymes in organic synthesis, 11. Enantioselective lactonization of methyl 3, 5dihydroxyalkanoates. An access to (3R,5S,6E)-3-hydroxy-7phenyl-6-hepten-5-olide by enzyme-catalyzed kinetic resolution in organic solvents," Liebigs Annalen der Chemie, vol. 8, pp. 809-811, 1992.

[61] F. Bennett, D. W. Knight, and G. Fenton, "An alternative approach to mevinic acid analogues from methyl (3R)-(-)-3hydroxyhex-5-enoate and an extension to unambiguous syntheses of (6R)-(+)-and (6S)-(-)-goniothalamin," Journal of the Chemical Society, Perkin Transactions 1, no. 3, pp. 519-523, 1991.

[62] Â. de Fátima, L. K. Kohn, M. A. Antônio, J. E. de Carvalho, and R. A. Pilli, "(R)-Goniothalamin: total syntheses and cytotoxic activity against cancer cell lines," Bioorganic and Medicinal Chemistry, vol. 13, no. 8, pp. 2927-2933, 2005.
[63] B. Das, S. Nagendra, and C. R. Reddy, "Stereoselective total synthesis of (+)-cryptofolione and (+)-goniothalamin," Tetrahedron Asymmetry, vol. 22, no. 11, pp. 1249-1254, 2011.

[64] L. Fournier, P. Kocienski, and J. Pons, "The $\beta$-lactone route to $\alpha, \beta$-unsaturated $\delta$-lactones. Total syntheses of $( \pm)$ goniothalamin and (-)-massoialactone," Tetrahedron, vol. 60, no. 7, pp. 1659-1663, 2004.

[65] D. B. Vendramini-Costa, I. B. D. D. Castro, A. L. T. G. Ruiz, C. Marquissolo, R. A. Pilli, and J. E. D. Carvalho, "Effect of goniothalamin on the development of Ehrlich solid tumor in mice," Bioorganic and Medicinal Chemistry, vol. 18, no. 18, pp. 6742-6747, 2010.

[66] S. H. Inayat-Hussain, L. T. Wong, K. M. Chan et al., "RACK1 overexpression protects against goniothalamin-induced cell death," Toxicology Letters, vol. 191, no. 2-3, pp. 118-122, 2009.

[67] S. H. Inayat-Hussain, B. O. Annuar, L. B. Din, A. M. Ali, and D. Ross, "Loss of mitochondrial transmembrane potential and caspase- 9 activation during apoptosis induced by the novel styryl-lactone goniothalamin in HL-60 leukemia cells," Toxicology in Vitro, vol. 17, no. 4, pp. 433-439, 2003.

[68] C. Wattanapiromsakul, B. Wangsintaweekul, P. Sangprapan, A. Itharat, and N. Keawpradub, "Goniothalamin, a cytotoxic compound, isolated from Goniothalamus macrophyllus (Blume) Hook. f. \& Thomson var. macrophyllus," The Songklanakarin Journal of Science and Technology, vol. 27, Article ID 479487, 2005.

[69] N. Umar-Tsafe, M. S. Mohamed-Said, R. Rosli, L. B. Din, and L. C. Lai, "Genotoxicity of goniothalamin in CHO cell line," Mutation Research, vol. 562, no. 1-2, pp. 91-102, 2004.

[70] Â. de Fátima, W. F. Zambuzzi, L. V. Modolo et al., "Cytotoxicity of goniothalamin enantiomers in renal cancer cells: involvement of nitric oxide, apoptosis and autophagy," ChemicoBiological Interactions, vol. 176, no. 2-3, pp. 143-150, 2008.

[71] A. C. S. Souza, Â. de Fátima, R. B. da Silveira, and G. Z. Justo, "Seek and destroy: the use of natural compounds for targeting the molecular roots of cancer," Current Drug Targets, vol. 13, no. 8, pp. 1072-1082, 2012.

[72] M. Al-Qubaisi, R. Rozita, S. K. Yeap, A. R. Omar, A. M. Ali, and N. B. Alitheen, "Selective cytotoxicity of goniothalamin against hepatoblastoma HepG2 cells," Molecules, vol. 16, no. 4, pp. 29442959, 2011.

[73] M. Al-Qubaisi, R. Rosli, T. Subramani et al., "Goniothalamin selectively induces apoptosis on human hepatoblastoma cells through caspase-3 activation," Natural Product Research, vol. 27, no. 23, pp. 2216-2218, 2013.

[74] A. M. Ali, M. M. Mackeen, M. Hamid et al., "Cytotoxicity and electron microscopy of cell death induced by goniothalamin," Planta Medica, vol. 63, no. 1, pp. 81-83, 1997.

[75] A. H. L. Pihie, J. Stanslas, and L. B. Din, "Non-steroid receptormediated antiproliferative activity of styrylpyrone derivative in human breast cancer cell lines," Anticancer Research, vol. 18, no. 3, pp. 1739-1743, 1998.

[76] A. L. T. Chien and A. H. L. Pihie, "Styrylpyrone derivative induces apoptosis through the up-regulation of Bax in the human breast cancer cell line MCF-7," Journal of Biochemistry and Molecular Biology, vol. 36, no. 3, pp. 269-274, 2003.

[77] P. L. Teoh and L. Azimahtol Hawariah, "Effects of goniothalamin of bcl-2 and bax genes in human ovarian carcinoma cell line, CaOV-3," Malaysian Applied Biology Journal, vol. 28, pp. 113-118, 2000. 
[78] K. M. Chan, N. F. Rajab, M. H. A. Ishak et al., "Goniothalamin induces apoptosis in vascular smooth muscle cells," ChemicoBiological Interactions, vol. 159, no. 2, pp. 129-140, 2006.

[79] K. M. Chan, N. F. Rajab, D. Siegel, L. B. Din, D. Ross, and S. H. Inayat-Hussain, "Goniothalamin induces coronary artery smooth muscle cells apoptosis: the p53-dependent caspase-2 activation pathway," Toxicological Sciences, vol. 116, no. 2, pp. 533-548, 2010.

[80] N. F. Rajab, Z. A. Hamid, H. Hassan, M. A. Ali, L. B. Din, and S. H. Inayat-Hussain, "Evaluation of the cytotoxic and genotoxic effects of goniothalamin in leukemic cell lines," Environmental Mutagen Research, vol. 27, pp. 161-164, 2005.

[81] S. H. Inayat-Hussain, A. B. Osman, L. B. Din et al., "Caspases3 and -7 are activated in goniothalamin-induced apoptosis in human Jurkat T-cells," FEBS Letters, vol. 456, no. 3, pp. 379-383, 1999.

[82] S. H. Inayat-Hussain, K. M. Chan, N. F. Rajab et al., "Goniothalamin-induced oxidative stress, DNA damage and apoptosis via caspase-2 independent and Bcl-2 independent pathways in Jurkat T-cells," Toxicology Letters, vol. 193, no. 1, pp. 108-114, 2010.

[83] B. Orlikova, M. Schumacher, T. Juncker et al., "Styryl-lactone goniothalamin inhibits TNF- $\alpha$-induced NF- $\kappa \mathrm{B}$ activation," Food and Chemical Toxicology, vol. 59, pp. 572-578, 2013.

[84] P. Petsophonsakul, W. Pompimon, and R. Banjerdpongchai, "Apoptosis induction in human leukemic promyelocytic HL-60 and monocytic U937 cell lines by Goniothalamin," Asian Pacific Journal of Cancer Prevention, vol. 14, no. 5, pp. 2885-2889, 2013.

[85] K. K. Kuo, Y. L. Chen, L. R. Chen et al., "Involvement of phorbol12-myristate-13-acetate-induced protein 1 in goniothalamininduced TP53-dependent and -independent apoptosis in hepatocellular carcinoma-derived cells," Toxicology and Applied Pharmacology, vol. 256, no. 1, pp. 8-23, 2011.

[86] S. C. Semprebon, Â. de Fátima, S. R. Lepri, D. Sartori, L. R. Ribeiro, and M. S. Mantovani, "(S)-goniothalamin induces DNA damage, apoptosis, and decrease in BIRC5 messenger RNA levels in NCI-H460 cells," Human and Experimental Toxicology, vol. 33, no. 1, pp. 3-13, 2014.

[87] C. C. Chiu, P. L. Liu, K. J. Huang et al., "Goniothalamin inhibits growth of human lung cancer cells through DNA damage, apoptosis, and reduced migration ability," Journal of Agricultural and Food Chemistry, vol. 59, no. 8, pp. 4288-4293, 2011.

[88] C.-Y. Yen, C.-C. Chiu, R.-W. Haung et al., "Antiproliferative effects of goniothalamin on Ca9-22 oral cancer cells through apoptosis, DNA damage and ROS induction," Mutation Research/Genetic Toxicology and Environmental Mutagenesis, vol. 747, no. 2, pp. 253-258, 2012.

[89] A. M. Alabsi, R. Ali, A. M. Ali et al., "Apoptosis induction, cell cycle arrest and in vitro anticancer activity of gonothalamin in a cancer cell lines," Asian Pacific Journal of Cancer Prevention, vol. 13, no. 10, pp. 5131-5136, 2012.

[90] A. M. Alabsi, R. Ali, A. M. Ali et al., "Induction of caspase-9, biochemical assessment and morphological changes caused by apoptosis in cancer cells treated with goniothalamin extracted from Goniothalamus macrophyllus," Asian Pacific Journal of Cancer Prevention, vol. 14, no. 11, pp. 6273-6280, 2013.

[91] J. J. Cohen, "Apoptosis: the physiologic pathway of cell death," Hospital Practice, vol. 28, no. 12, pp. 35-43, 1993.

[92] D. Ren, G. Peng, C. H. Huang, B. H. Wang, and S. Zhang, "Effect of rhodoxanthin from Potamogeton crispus L. on cell apoptosis in Hela cells," Toxicology in Vitro, vol. 20, no. 8, pp. 1411-1418, 2006.

[93] A. Murakami, R. Hayashi, T. Takana, K. H. Kwon, H. Ohigashi, and R. Safitri, "Suppression of dextran sodium sulfateinduced colitis in mice by zerumbone, a subtropical ginger sesquiterpene, and nimesulide: separately and in combination," Biochemical Pharmacology, vol. 66, no. 7, pp. 1253-1261, 2003.

[94] F. Oberhammer, J. W. Wilson, C. Dive et al., "Apoptotic death in epithelial cells: cleavage of DNA to $300 \mathrm{and} /$ or $50 \mathrm{~kb}$ fragments prior to or in the absence of internucleosomal fragmentation," The EMBO Journal, vol. 12, no. 9, pp. 3679-3684, 1993.

[95] J. L. Gooch and D. Yee, "Strain-specific differences in formation of apoptotic DNA ladders in MCF-7 breast cancer cells," Cancer Letters, vol. 144, no. 1, pp. 31-37, 1999.

[96] S. Zhao, Y. Yang, and J. Song, "Ceramide induces caspasedependent and -independent apoptosis in A-431 cells," Journal of Cellular Physiology, vol. 199, no. 1, pp. 47-56, 2004.

[97] W. K. Lee, M. Abouhamed, and F. Thévenod, "Caspasedependent and -independent pathways for cadmium-induced apoptosis in cultured kidney proximal tubule cells," The American Journal of Physiology: Renal Physiology, vol. 291, no. 4, pp. F823-F832, 2006.

[98] M. H. Kang and C. P. Reynolds, "BcI-2 Inhibitors: targeting mitochondrial apoptotic pathways in cancer therapy," Clinical Cancer Research, vol. 15, no. 4, pp. 1126-1132, 2009.

[99] S. J. Riedl and G. S. Salvesen, "The apoptosome: signalling platform of cell death," Nature Reviews Molecular Cell Biology, vol. 8, no. 5, pp. 405-413, 2007.

[100] J. R. Bertino, "Irinotecan for colorectal cancer," Seminars in Oncology, vol. 24, pp. S18-S23, 1997.

[101] S. H. Inayat-Hussain, A. B. Osman, L. B. Din, and N. Taniguchi, "Altholactone, a novel styryl-lactone induces apoptosis via oxidative stress in human HL-60 leukemia cells," Toxicology Letters, vol. 131, no. 3, pp. 153-159, 2002.

[102] P. S. Schwartz and D. M. Hockenbery, "Bcl-2-related survival proteins," Cell Death and Differentiation, vol. 13, no. 8, pp. 12501255, 2006.

[103] H. Zou, Y. Li, X. Liu, and X. Wang, "An APAF-1.cytochrome C multimeric complex is a functional apoptosome that activates procaspase-9," The Journal of Biological Chemistry, vol. 274, no. 17, pp. 11549-11556, 1999.

[104] A. Tinel and J. Tschopp, "The PIDDosome, a protein complex implicated in activation of caspase- 2 in response to genotoxic stress," Science, vol. 304, no. 5672, pp. 843-846, 2004.

[105] R. L. Noble, "The discovery of the vinca alkaloidschemotherapeutic agents against cancer," Biochemistry and Cell Biology, vol. 68, no. 12, pp. 1344-1351, 1990.

[106] H. Stähblin, "Activity of a new glycosidic lignan derivative (VP 16-213) related to podophyllotoxin in experimental tumors," European Journal of Cancer, vol. 9, no. 3, pp. 215-221, 1973.

[107] A. L. Harvey, "Medicines from nature: are natural products still relevant to drug discovery?" Trends in Pharmacological Sciences, vol. 20, no. 5, pp. 196-198, 1999.

[108] L. F. Liu, "DNA topoisomerase poisons as antitumor drugs," Annual Review of Biochemistry, vol. 58, pp. 351-375, 1989.

[109] M. C. Wani, H. L. Taylor, M. E. Wall, P. Coggon, and A. T. McPhail, "Plant antitumor agents, VI: the isolation and structure of taxol, a novel antileukemic and antitumor agent from Taxus brevifolia," Journal of the American Chemical Society, vol. 93, no. 9, pp. 2325-2327, 1971. 
[110] G. J. Creemers, G. Bolis, M. Gore et al., "Topotecan, an active drug in the second-line treatment of epithelial ovarian cancer," Journal of Clinical Oncology, vol. 14, no. 12, pp. 3056-3061, 1996.

[111] L. F. Liu, S. D. Desai, T. K. Li, Y. Mao, M. Sun, and S. Sim, "Mechanism of action of camptothecin," Annals of the New York Academy of Sciences, vol. 922, pp. 1-10, 2000. 

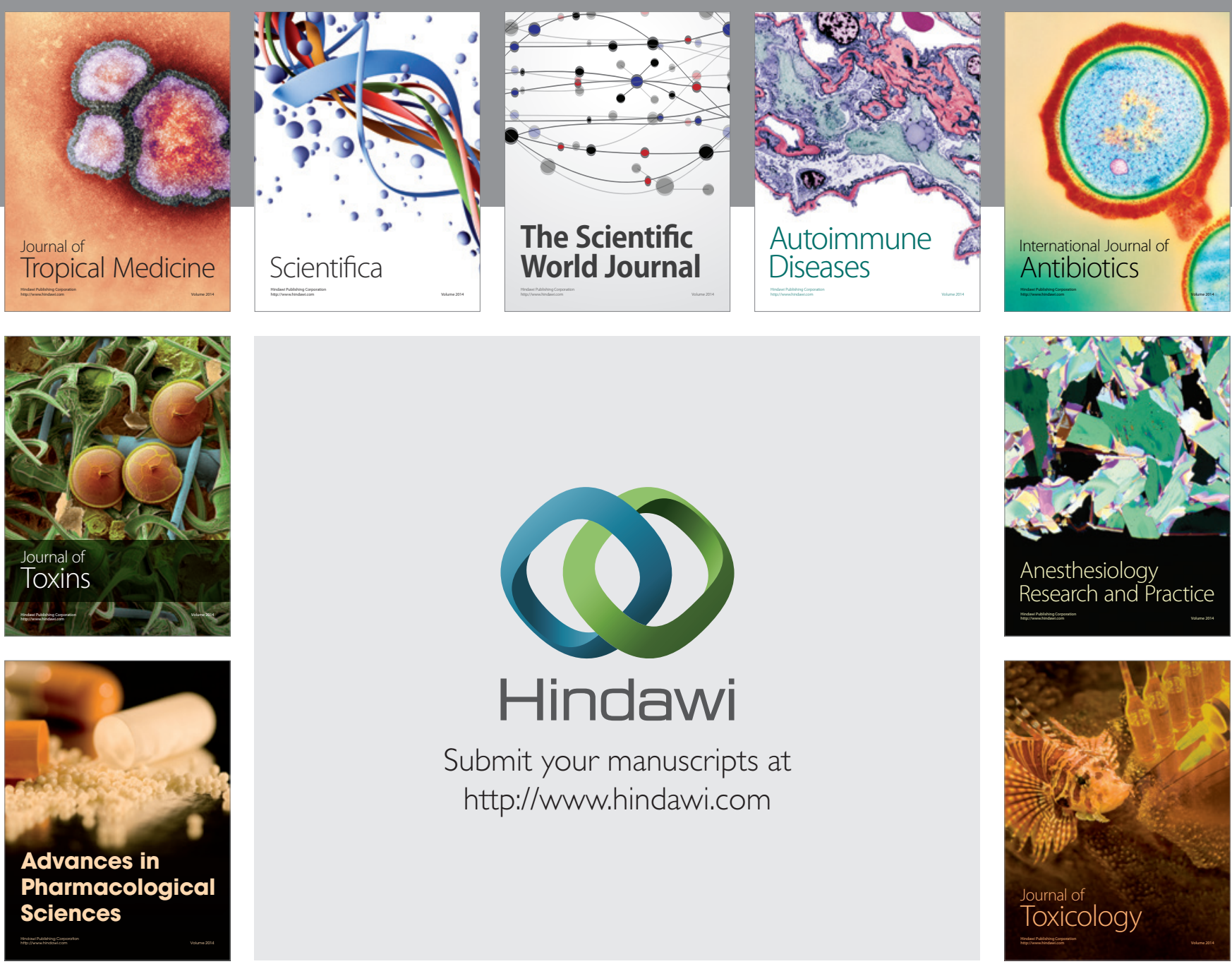

\section{Hindawi}

Submit your manuscripts at

http://www.hindawi.com
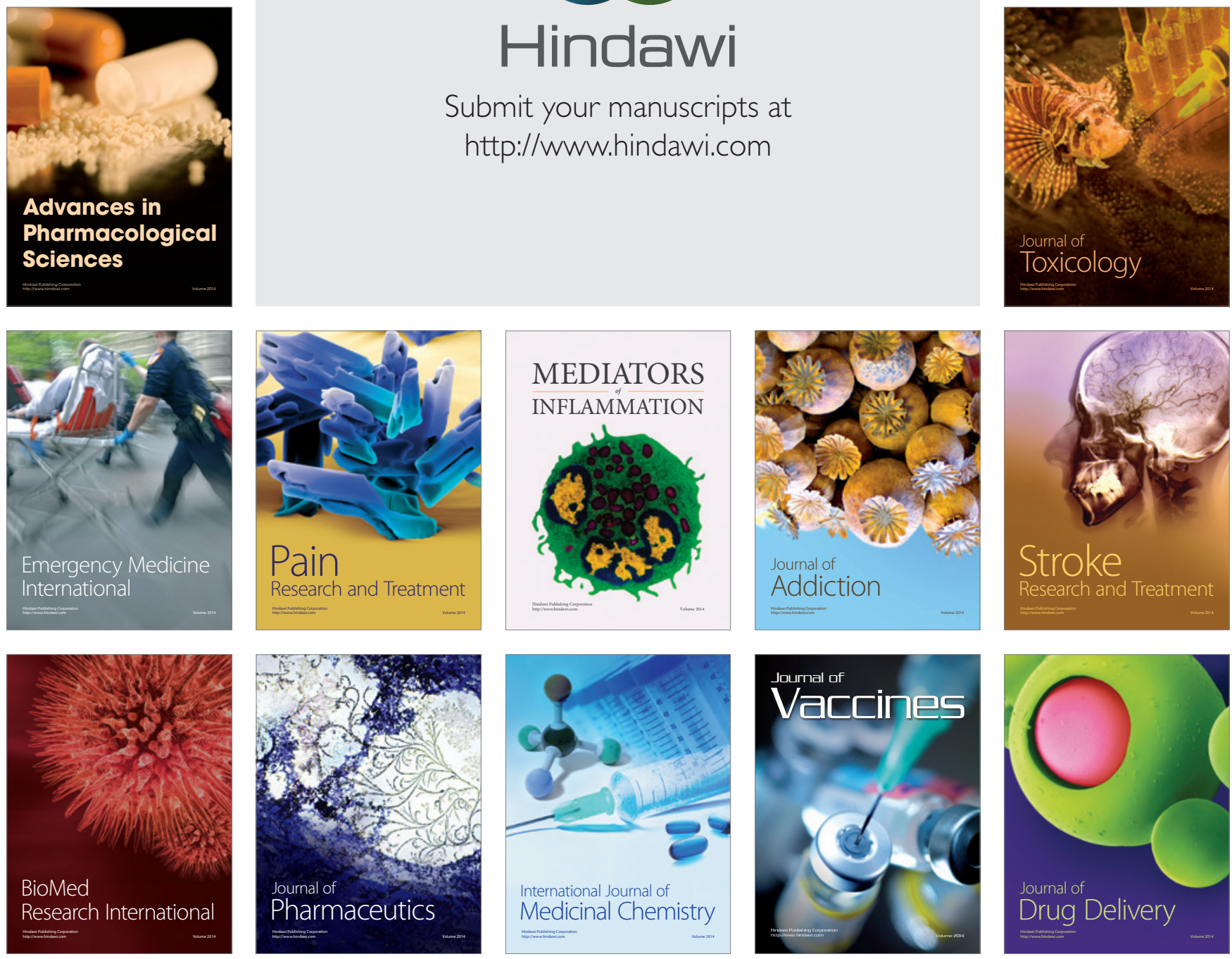